\title{
Research
}

\section{Linking Hunter Knowledge with Forest Change to Understand Changing Deer Harvest Opportunities in Intensively Logged Landscapes}

\author{
$\underline{\text { Todd J. Brinkman }}^{1}, \underline{\text { Terry Chapin }}^{1}$, Gary Kofinas $^{1}$, and David K. Person $^{2}$
}

\begin{abstract}
The effects of landscape changes caused by intensive logging on the availability of wild game are important when the harvest of wild game is a critical cultural practice, food source, and recreational activity. We assessed the influence of extensive industrial logging on the availability of wild game by drawing on local knowledge and ecological science to evaluate the relationship between forest change and opportunities to harvest Sitka black-tailed deer (Odocoileus hemionus sitkensis) on Prince of Wales Island, Alaska. We used data collected through interviews with local deer hunters and GIS analysis of land cover to determine relationships among landscape change, hunter access, and habitat for deer hunting over the last $50 \mathrm{yr}$. We then used these relationships to predict how harvest opportunities may change in the future. Intensive logging from 1950 into the 1990s provided better access to deer and habitat that facilitated deer hunting. However, successional changes in intensively logged forests in combination with a decline in current logging activity have reduced access to deer and increased undesirable habitat for deer hunting. In this new landscape, harvest opportunities in previously logged landscapes have declined, and hunters identify second-growth forest as one of the least popular habitats for hunting. Given the current state of the logging industry in Alaska, it is unlikely that the logging of the remaining old-growth forests or intensive management of second-growth forests will cause hunter opportunities to rebound to historic levels. Instead, hunter opportunities may continue to decline for at least another human generation, even if the long-term impacts of logging activity and deer harvest on deer numbers are minimal. Adapting hunting strategies to focus on naturally open habitats such as alpine and muskeg that are less influenced by external market forces may require considerably more hunting effort but provide the best option for sustaining deer hunting as a local tradition over the long run. We speculate that managing deer habitat in accessible areas may be more important than managing the overall health of deer populations on a regional scale. We further suggest that the level of access to preferred hunting habitat may be just as important as deer densities in determining hunter efficiency.
\end{abstract}

Key Words: access; forest change; hunting; local knowledge; logging; Odocoileus hemionus sitkensis; Sitka black-tailed deer; subsistence

\section{INTRODUCTION}

Industrial-scale harvesting of timber has altered landscapes around the world and changed the ways in which hunters interact with local forests (Robinson et al. 1999). For many of these hunters, the harvesting of wildlife is an important cultural practice, food source, and recreational activity (Rao and McGowan 2002, Wolfe 2004) that helps to strengthen the connections between people and their environment. Commercial logging usually results in the construction of roads that alter access to hunting areas, in changes in habitats that influence populations of game, and in an influx of nonlocal timber workers. It is therefore important to understand the relationships between the harvesting of wildlife and the rapid social and environmental changes caused by logging. Although those relationships have been evaluated in tropical forests (Robinson and Bennett 2000), little attention has been paid to the effects of intensive logging on subsistence hunters who depend on wildlife in temperate regions. Temperate-zone studies have compared harvest data on wild game in logged and unlogged forests (Hieb 1976) and documented deer response to logging activity and changes in forage

${ }^{1}$ University of Alaska-Fairbanks, ${ }^{2}$ Alaska Department of Fish and Game 
availability following clear-cutting (e.g., Wallmo and Schoen 1980, Cambell et al. 2004, Doerr et al. 2005). Other studies have explored the influence of hunters on deer in logged areas (Martin and Baltzinger 2002, Farmer et al. 2006), but not the influence of logging on deer hunters. We found no studies that specifically addressed how and why deer harvest opportunities changed over time in logged areas.

We investigated the subsistence hunting of Sitka black-tailed deer (Odocoileus hemionus sitkensis) on Prince of Wales Island, Alaska. Intensive logging has significantly altered landscapes on Prince of Wales over the last $50 \mathrm{yr}$. Because the availability of wildlife is critically important to people dependent on the resource for food and cultural identity, we drew upon the perceptions and knowledge of local hunters to identify how the increase and subsequent decline in commercial logging have affected their harvest opportunities. Local knowledge, i.e., traditional ecological knowledge, has provided insight into the effects of land management decisions and human-use impacts on long-term ecological composition, structure, and function (Watson et al. 2003). Further, a number of researchers argue that merging local knowledge with science is an effective approach to sustainable monitoring and management of local wild resources (Kofinas et al. 2002, Folke 2004, Berkes 2008).

Our objective was to determine how opportunities to harvest wildlife changed spatially and temporally in intensively logged landscapes with changes in access to hunting areas and changes in forest age structure as the logged stands transition through the successional stages following a clearcut. We also considered options for adaptation by which institutions and individual hunters might respond to the effects of logging to sustain harvesting efficiency and cultural identity.

\section{STUDY AREA}

Prince of Wales Island near the south end of the southeastern region of Alaska is the third largest island in the United States (Fig. 1). Rugged mountains extending up to $1160 \mathrm{~m}$ in elevation and long fjords characterize much of the topography on the island. Habitats below $600 \mathrm{~m}$ are dominated by temperate coniferous rain forest consisting primarily of Sitka spruce (Picea sitchensis) and western hemlock (Tsuga heterophylla; Alaback
1982). Annual precipitation varies from 130 to 400 $\mathrm{cm}$, and mean monthly temperature ranges from $1^{\circ}$ C in January to $13^{\circ} \mathrm{C}$ in July. Most of Prince of Wales is within the Tongass National Forest, which is administered by the U.S. Forest Service.

Before the mid-1900s, Prince of Wales was occupied primarily by Tlingit and Haida Indians, who lived in numerous small coastal fishing villages (Langdon 1977, Emmons 1991) and depended largely on marine resources such as wild salmon (Oncorhynchus spp.). Prior to the mid-1900s, deer were hunted along shorelines in conjunction with marine harvesting activities (Ellanna and Sherrod 1987). Intensive logging between 1950 and 1990 led to the construction of roads, changes in forest habitat, and a dramatic increase in the human population, particularly in the number of nonindigenous forest workers, who moved from the Pacific Northwest region of the continental United States. Greater access via logging roads increased the availability of deer and the dependence of local residents on deer meat. Many temporary logging camps became permanent communities during the 1960s and 1970s. In 1974, ferry service linked Prince of Wales to other parts of Alaska, Canada, and the continental United States, which further changed its community demographics. Prince of Wales currently has about 3500 residents, of whom $40 \%$ are Alaska natives, residing in 11 communities, some of which are populated with mixed native and non-native residents and others of which are more homogeneous.

Deer represents the most significant terrestrial source of meat for both indigenous and nonindigenous residents and is the most important big-game species for both subsistence and sport hunting in southeast Alaska (Kruse and Frazier 1988, Turek 1998, Alaska Department of Fish and Game 2001, Mazza 2003). Although there is limited documentation on early historical and precontact levels of deer harvesting, deer have probably always been a major source of red meat for the people of southeast Alaska (Ellana and Sherrod 1987). The number of hunters and the number of deer harvested on Prince of Wales Island have not changed significantly over the last $25 \mathrm{yr}$ (Mazza 2003). The total subsistence harvest of wild food in rural areas of southeast Alaska is estimated at $81 \mathrm{~kg} /$ person annually, with an estimated replacement value of $U$. S. \$11/kg (Alaska Department of Fish and Game 2000). An average of $73 \%$ of households used deer as a subsistence resource, with deer representing 
Fig. 1. Location of the Alexander Archipelago and Prince of Wales Island in southeast Alaska.

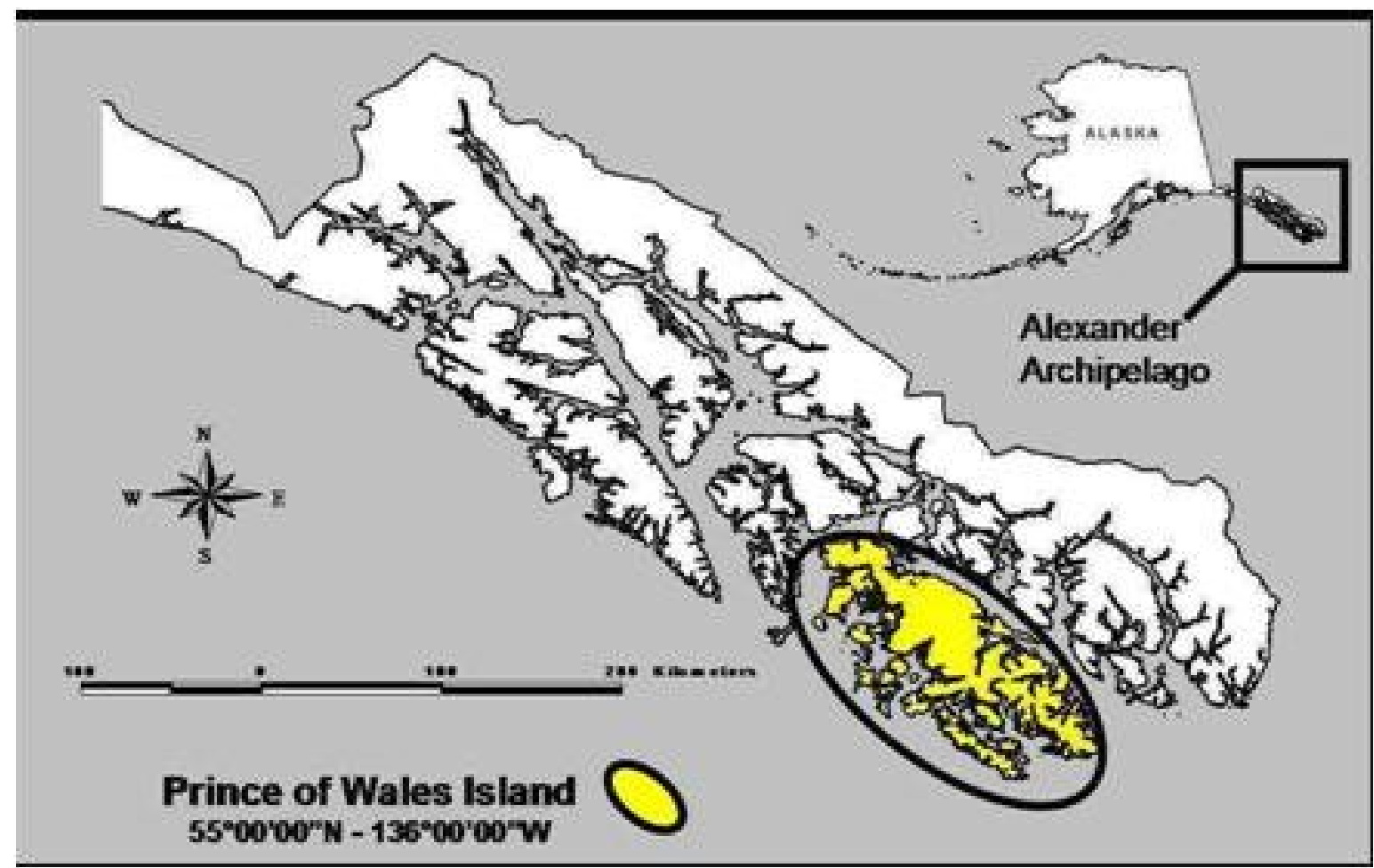

approximately $20 \%$, in terms of usable weight, of the total subsistence harvest (Alaska Department of Fish and Game 2001). Purchasing a replacement for deer meat would cost U.S. $\$ 712$ for a family of four. Communities on Prince of Wales Island that have increased their per capita deer harvest generally also showed an increase in the number of people living below the federal poverty level (Mazza 2003). More difficult to quantify, but equally important, is the cultural significance of hunting, harvesting, sharing, and consuming deer. Sharing of deer meat among households is common among indigenous and nonindigenous households, and Alaska natives use deer for potlatches, ceremonies, and funeral feasts (Turek et al. 1998).

Prince of Wales and adjacent islands constitute Game Management Unit 2 (GMU2) as designated by the Alaska Department of Fish and Game. For residents of Prince of Wales, deer hunting season is open from the end of July through December, with a harvest limit of five deer annually, one of which may be antlerless. Hunters may harvest more than five deer each year by acquiring a special permit, e. g., a designated permit, that allows a hunter to harvest deer for others who are unable to hunt for themselves. Reliable estimates of the deer harvest are unavailable (Southeast Alaska Subsistence Regional Advisory Council 2005), but the total harvest is thought to be around 6000 deer, with most being taken by island residents and the neighboring off-island communities of Ketchikan and Saxmon. Although the population of deer on Prince of Wales Island has been roughly estimated at 55,000 deer (Porter 2005), there are no population data available that are accurate and precise enough to assess population trends at the temporal and spatial scales required for comparisons with changes in forest habitat and harvest opportunities. Because the island's interior was mostly uninhabited and unhunted before commercial logging (Emmons 1991), there is no information on prelogging deer populations, although descriptive accounts suggest deer were abundant (Osgood 1901, Klein and Olson 1960). 
Industrial-scale timber harvesting began on Prince of Wales and adjacent islands in the mid-1950s. From 1954 to 2005 , approximately $1800 \mathrm{~km}^{2}$ of forest were harvested on U.S. Forest Service, state, and native-corporation lands, representing $20 \%$ of the total land area. South-facing productive oldgrowth forest below $300 \mathrm{~m}$ is considered critical winter habitat for deer (Wallmo and Schoen 1980). More than $50 \%$ of that habitat has been commercially harvested for timber. To facilitate logging, the highest density of roads in southeast Alaska was constructed in areas that penetrated previously remote deer habitat. At least $4000 \mathrm{~km}$ of roads were built on the above-mentioned lands (Southeast Alaska GIS Library 2007). Currently, approximately $2900 \mathrm{~km}$ are open for passengervehicle travel, with $2300 \mathrm{~km}$ under U.S. Forest Service control. Many roads have been closed by gating, the removal of culverts and bridges, and the overgrowth of trees. In the late 1990s, poor markets for timber and environmental litigation to prevent clear-cut logging combined to severely reduce timber harvesting in the region. Indeed, 590 million board-feet ( $\mathrm{mmb}$ ) of timber were harvested annually from the Tongass National Forest in peak years during the 1970s, but by 2003, the harvest had declined to $<51 \mathrm{mmb}$ (U.S. Department of Agriculture 2007).

During peak timber harvesting, most roads were suitable for motorized vehicles, which provided easy access to open habitats such as muskeg heaths and clearcuts suitable for hunting deer (Mazza 2003). Hunters no longer had to hike long distances from boats to open alpine habitat or restrict their hunting forays to beaches. They were able to exploit large areas of Prince of Wales and adjacent islands that had previously been inaccessible, and the harvest increased per unit effort. Deer hunters responded to increased road access by switching from boat-based hunting to vehicles (Ellanna and Sherrod 1987, Brinkman et al. 2007), an adaptation that helped hunters overcome restrictions characteristic of boat hunting, e.g., weather dependence, long travel distances to hunting area, and cost.

Road construction and maintenance on Prince of Wales Island depend mostly on revenues from logging (PBS Engineering and Environmental 2005), but, as a result of the recent decline in the activities of the timber industry, existing roads are being decommissioned more quickly than new ones are being built. According to the U.S. Forest Service
(PBS Engineering and Environmental 2005), an additional $1500 \mathrm{~km}$ of roads, or approximately $50 \%$ of current road network, are designated to be temporarily or permanently closed to passenger vehicle traffic over the next $10 \mathrm{yr}$, leaving a road network of roughly $1900 \mathrm{~km}$. Although some new road construction may occur to meet future logging needs, the kilometers of road built will probably be small relative to the length of the roads being closed. The market for timber from Alaska is unlikely to rebound soon and may never again reach historically high levels (Morse 2000, Brackley et al. 2006; L. K. Crone, unpublished manuscript).

Because of intensive logging, deer may shift their patterns of activity in response to forest succession, and the density of deer may decline as even-aged young-growth stands progress beyond shrub and sapling stages to stem-exclusion forests (Wallmo and Schoen 1980). Stem exclusion occurs about 25$30 \mathrm{yr}$ after a stand is clear-cut and is characterized by thick unbroken forest canopies and sparse understory vegetation (Alaback 1982). Forage biomass for deer in these stands may be $<5 \%$ of that present in young $(<20 \mathrm{yr})$ clearcuts. However, data are unavailable on how deer respond to these changes in forest structure.

\section{METHODS}

\section{Identification of interview subjects}

We used Alaska Department of Fish and Game records as well as informal community interviews conducted during the summer of 2004 to locate experienced hunters to participate in structured interviews. In some communities, we hired the environmental planner who worked for the local Alaska native village corporation to assist with the selection of interview subjects. After an initial group of key hunters was identified in each community, peer selection and chain referral methods, i.e., the snowball method, were used to locate additional interview candidates. We attempted to interview the most active hunters who concentrated their efforts in GMU2. We assumed that these hunters had an above-average understanding of hunting patterns, deer populations, and deer habitat. Because we interviewed adult Alaskan residents (native and non-native) who were considered to have an indepth knowledge of deer and deer hunting, our data should not be interpreted as representative of all deer hunters on Prince of Wales. Instead, our sample 
represented the knowledge and perceptions of seasoned deer hunters who were particularly dependent on deer.

\section{Interview topics}

During the spring and summer of 2005, we used a semistructured set of open-ended and quantifiable questions to guide face-to-face interviews with residents on Prince of Wales and two off-island communities. The interview served to collect hunter perceptions and knowledge in three main areas: (1) deer hunting patterns, (2) deer population trends, and (3) deer habitat and access. The off-island communities of Ketchikan and Saxmon, Alaska, were included in the study because many residents of those communities commonly hunt deer on Prince of Wales and depend on the resource. Along with interview questions, we asked each participant to answer a short self-administered questionnaire. We digitally recorded interviews and also took handwritten notes. Most interviews were conducted in the respondents' work or home settings. We protected the anonymity of the respondents. All methods and questions were approved by the University of Alaska Fairbanks Institutional Review Board (\#05-30) prior to the interview process.

We evaluated hunter access by asking the interviewees about mode of travel to hunting areas, e.g., foot, boat, vehicle; distance from home to hunting area; distance traveled on foot while hunting; and how road construction and road closures have affected their choice of hunting location, strategy, effort, success, and the island's deer population. We investigated hunter perceptions of habitat change in their hunting areas by asking if, how, and when they changed location, effort, and strategy in response to changing forest structure. Hunters were asked to rank major habitat types, e. g., clearcuts, old-growth forest as defined below, on Prince of Wales based on hunting preference. Hunters were also asked how harvest opportunities change as a clearcut transitions to second-growth forest. There are no empirical data with respect to the response of deer population size to forest change. Although we asked interview participants to share their perceptions of how deer abundance may have responded to habitat change, we did not include these hunter perceptions in our analysis because there was no consensus among hunters about population trends, and the variance among hunters was too large to identify relationships with habitat change.

\section{Data analysis methods}

We estimated mean values for normally distributed data and medians when data were asymmetrically distributed, i.e., when the ratio of skewness or kurtosis to its standard error was less than -2 or greater than +2 . Data were coded and analyzed using the computer program SPSS 12.0.1 (SPSS Inc., Chicago, Illinois, USA). Chi-square tests were used to test for associations between categorical variables. We used Student's $t$ tests to compare variables grouped within two categories and oneway analysis of variance (ANOVA) to compare scales and categorical variables grouped among > two factors. Homogeneity of variance test was used to test for the equality of group variances. The Welch statistic was used to test for differences when group variances were unequal. We used a nonparametric Mann-Whitney $U$ test with two independent samples and the Kruskal-Wallis test with several independent samples to determine significant differences when samples were not normally distributed.

We categorized habitat for deer hunting on Prince of Wales Island into seven major land-cover types: (1) old-growth forest, (2) alpine tundra, (3) muskeg, (4) beach, (5) clear-cut forest, (6) second-growth forest, and (7) precommercially thinned forest. Oldgrowth forest usually consists of large old conifers undisturbed by logging, with pockets of understory vegetation such as Vaccinium spp., Oplopanax horridus, and Lysichiton americanum (Pojar 1994). Alpine tundra is treeless habitat usually at an altitude above $800 \mathrm{~m}$ that is dominated by low-growing plants adapted to snow pack and wind abrasion; this habitat is commonly occupied by migrating deer during the snow-free months (U.S. Department of Agriculture 2007). Muskeg communities, also known as peatlands or heath, are poorly drained areas with few trees relative to old-growth forest and consist mainly of sphagnum mosses (Sphagnum spp.) and sedges (Carax spp.; U.S. Department of Agriculture 2007). Beach is tidal shoreline habitat that may contain grass and sedge meadows in flat lowlands. During times of deep snow accumulation, deer may aggregate in these areas because they are the last areas to accumulate snow. Clearcuts are forest areas harvested using an even-aged management strategy, the predominant strategy in 
southeast Alaska, in which all the trees are felled within a stand regardless of their value. Conifer trees regenerate naturally within clear-cut stands. One to nine yr after logging, young clearcuts generally are open and seedling trees are $<2 \mathrm{~m}$ high, enabling hunters to easily detect deer. In those early stages of succession, forage plants are abundant and available to deer during snow-free months. Ten to $25 \mathrm{yr}$ after logging, stands transition into a shrubsapling stage in which saplings are 2-6 $\mathrm{m}$ tall and visibility is very limited. Between 25 and $40 \mathrm{yr}$ after logging, clearcuts become second-growth forests that have high densities of young trees, thick forest canopies, and very limited understory vegetation (Alaback 1982). Those stands provide little forage for deer and are difficult to hunt because of poor visibility. Many 10- to 25-yr-old stands have been precommercially thinned, i.e., all the saplings within a specified radius of trees allowed to remain in the stand are cut prior to logging. Precommercially thinned stands are characterized by widely spaced trees $(5-7 \mathrm{~m})$, large gaps in the forest canopy, and thick piles of slash, i.e., downed trees, filling in the spaces between trees. Thinning stimulates rapid growth in the residual trees and can temporarily enhance understory vegetation 5-10 yr after thinning; however, thick slash may hinder hunting in this habitat. This forest type is intended for future commercial harvest. Because most ( 99\%) logging activity has occurred since 1950, old second-growth forests (> $80 \mathrm{yr}$ of age) are rare, and second harvests have not yet occurred on the island.

We used GIS data layers derived from U.S. Forest Service vegetation and land-management digitial databases for the Tongass National Forest to delineate important habitats used by hunters and deer. We used GIS program ArcView 3.3 and ArcMap 9.0 (ESRI, Redlands, California, USA) to quantify changes in logging activity, forest habitat composition, and road access through time. Metadata for the spatial data layers used were available at the Southeast Alaska GIS Library (2007). Data concerning the years in which roads were constructed were unavailable, but, because they were built to facilitate logging, the ages of the clear-cut stands adjacent to the roads enabled us to estimate the chronology of road construction (Fig. 2 ). We determined how accessible habitats that deer hunters considered popular were to vehicles at peak open road density, current road density, and planned road density in the future by summing the lengths of the roads that were open and closed to passenger vehicle travel within each polygon representing habitat type using Hawth's Analysis Tools in ArcMap 9.0 (Beyer 2007). We determined the area $\left(\mathrm{km}^{2}\right)$ of popular habitat types for deer hunting that was accessible by foot when hunting from a vehicle by buffering the past, present, and future road networks by the median distance that hunters travel on foot when hunting, and then summing the area of each habitat type within the buffered areas. Because the median distance that hunters travel away from their vehicles may not be perpendicular to the road, we also determined area $\left(\mathrm{km}^{2}\right)$ of popular habitat types within one-third of the median distance reported from roads. We assumed that the area within one-third of the median distance was a reasonable representation of the area readily accessible from the maintained road network.

\section{RESULTS}

We interviewed 88 deer hunters ( 31 native, 57 nonnative) from 11 communities on Prince of Wales and two off-island communities. Five females and 83 males were interviewed, and median interview length was $42 \mathrm{~min}$ (range $=1 \mathrm{hr} 27 \mathrm{~min}$ ). The mean age of the respondents was $47 \mathrm{yr}(\mathrm{SD}=13.7)$. The minimum age was $18 \mathrm{yr}$, and the maximum was 94 yr. The median years of experience hunting deer on Prince of Wales was 20 (range $=68$ ). The hunters interviewed harvested a mean of 6.1 deer $(\mathrm{SD}=5.6)$ per hunter during a typical hunting season, yielding roughly $109 \mathrm{~kg}$ of edible meat per hunter annually, with a food replacement value estimated at U.S. $\$ 1199$ per hunter (Alaska Department of Fish and Game 2000). When interview participants were grouped by race as native and non-native, responses were similar $(P>0.1)$ for 22 of the 25 questions that addressed hunter access and landscape change. Further, the key findings of this paper did not change when the groups were analyzed separately for the three questions to which responses differed. Consequently, we assumed that responses from native and non-native hunters were similar, and the data from the groups were pooled for the rest of our analyses.

\section{Access}

Vehicles were used most $(67 \%, \mathrm{SE}=5 \%)$ to access hunting areas, followed by the use of boats $(23 \%$, $\mathrm{SE}=5 \%$ ), and the rest of the hunters used a 
Fig. 2. Map of common landscape change between 1950 and 2015 within a watershed on Prince of Wales Island, Alaska. Map "2015" was based on projected road closures and harvest activity.

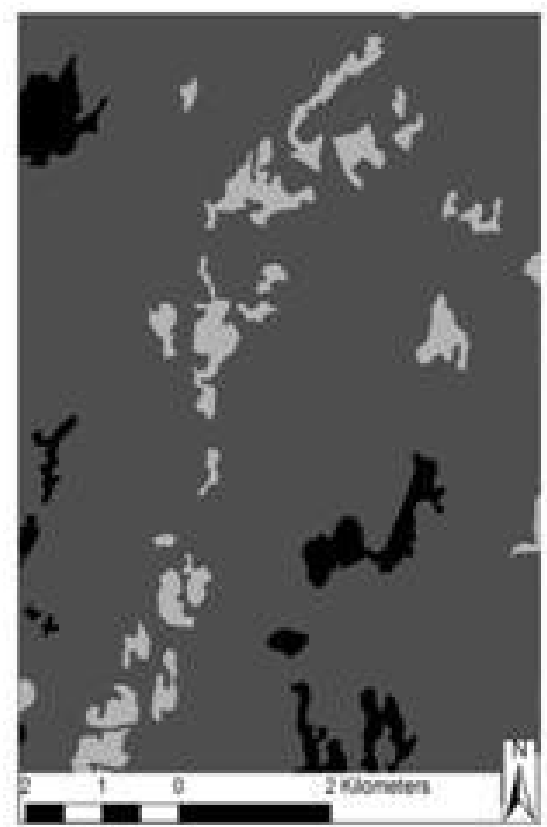

Pre looging

Okd growth forest

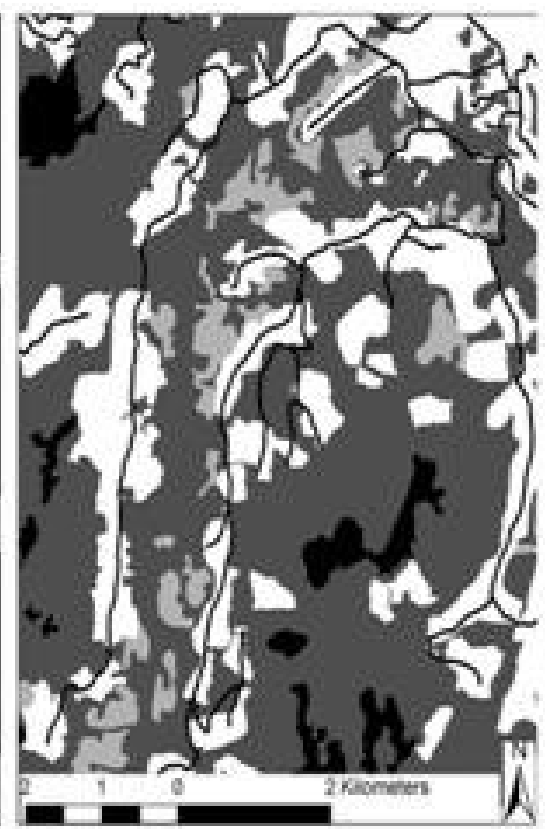

Year 2000

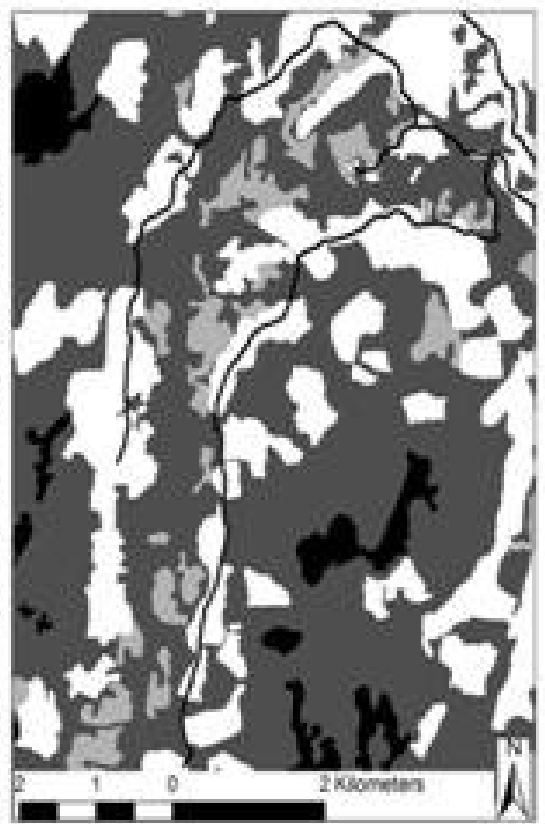

Year 2015 combination of boat, vehicle, ATV, and airplane $(10 \%, \mathrm{SE}=3 \%)$. After reaching the hunting area, hunters often traveled away from the vehicle or boat to hunt on foot (Table 1). Many hunters mentioned that they often hunt roads on foot, particularly closed roads. Thus, the distance traveled on foot does not necessarily equate to the distance traveled away from maintained roads. The typical distance traveled on foot was similar (Mann-Whitney $U=$ 244.5, $P=0.630$ ) between hunters using vehicles and hunters using boats, but hunters using vehicles (mean $=60 \mathrm{~km}, \mathrm{SD}=50.2 \mathrm{~km}$ ) traveled a greater distance (Mann-Whitney $U=493, P=0.001$ ) away from home than did hunters using boats ( mean $=22$, $\mathrm{SD}=16.0 \mathrm{~km})$.

\section{Hunting habitat}

Muskegs were identified as the most popular habitat type to hunt, followed by clearcuts (Table 2). Alpine was the third most popular habitat type for hunting and was considered the area that contains the largest and healthiest deer. Open terrain, low vegetative cover, and high visibility were the characteristics common to the habitats preferred by hunters. Older managed stands of forest, i.e., second growth, were the least popular for hunting because they impeded the hunters' ability to see deer and were thought to contain fewer deer. 
Table 1. Distance traveled in kilometers by vehicle or boat from home to hunting area and distance traveled away from boat or vehicle on foot when hunting, according to responses from deer hunters interviewed on Prince of Wales Island, Alaska.

\begin{tabular}{|c|c|c|c|c|}
\hline Hunting pattern & Minimum & Maximum & Median & SD \\
\hline $\begin{array}{l}\text { Typical distance traveled away from vehicle or boat when hunting } \\
\text { on foot }\end{array}$ & 0 & 10 & 3.2 & 2.2 \\
\hline Typical distance traveled away from home to hunt ${ }^{\dagger}$ & 3 & 176 & 32 & 50.3 \\
\hline
\end{tabular}

${ }^{\dagger}$ The distance traveled by off-island residents who used ferry access was measured from the Prince of Wales ferry terminal in Hollis, Alaska, to the hunting area.

\section{Linking access and hunting habitat}

Preferences for clearcuts (Mann-Whitney $U=266$, $P<0.001$ ), muskeg (Mann-Whitney $U=362.5, P$ $=0.007$ ), and beach (Mann-Whitney $U=320.0, P$ $=0.001)$ were different for hunters who traveled by boat compared to those who traveled by vehicle, but preferences for all other habitats were similar among groups (Table 2). The distance that hunters walked from their vehicles or boats when hunting did not influence their preference for any particular habitat type except alpine. Hunters who traveled above the median distance $(3.2 \mathrm{~km}$, range $=9.6)$ from their vehicles or boats preferred to hunt alpine habitat more than those traveling below the median (Mann-Whitney $U=537.5, P=0.009$ ).

As of 2006, $44.9 \mathrm{~km}$ of road accessed clearcuts 0 $8 \mathrm{yr}$ old, and $27.9 \mathrm{~km}^{2}$ and $31.9 \mathrm{~km}^{2}$ of young clearcut habitat was within 1.0 and $3.2 \mathrm{~km}$, which is the median distance that hunters travel on foot from their vehicles, of a maintained road, respectively. The length of road adjacent to muskeg habitat in 2006 was $125 \mathrm{~km}$. After projected road closures occur, the length of road adjacent to muskeg habitat will decline by $75 \mathrm{~km}(46 \%)$ from a peak of $138 \mathrm{~km}$. The length of road adjacent to alpine habitat in 2006 was $9 \mathrm{~km}$, similar to the peak open road network. After projected road closures, $2 \mathrm{~km}$ of road will be adjacent to alpine habitat. When comparing areas of muskeg and alpine habitat within 3.2 and $1.0 \mathrm{~km}$, which is considered immediately accessible area, from a road under different road densities, we determined that the area of muskeg habitat will decline by 17 and $32 \%$ within the $3.2-$ and $1.0-\mathrm{km}$ buffered areas, respectively (Fig. 3). Area of alpine habitat will decline by 8 and $35 \%$ within the $3.2-$ and 1.0-km buffered areas, respectively (Fig. 3). We were unable to identify the relationship between habitat availability and hunters' habitat preferences; however, we speculate that habitat popularity was likely influenced more by hunting characteristics such as visibility and vegetation type than by level of access or total area. Considering that clearcuts were less popular with boat hunters and shorelines were less popular with vehicle hunters, mode of access probably influences the popularity of certain habitat types.

\section{Relationships between forest change and deer harvest opportunities}

\section{Changes in road access}

Most hunters reported that the presence of roads increased their hunting success and decreased their effort (Table 3). However, their perceptions of the effect of road closures on hunting success and effort were mixed. Hunters generally believed that roads had a negative effect on deer populations and that road closures had a positive effect. Many added that hunting is better on new roads because of increased access to previously remote deer habitat and because new roads are usually located next to young 
Table 2. Ranking of preferred deer hunting areas by habitat type according to responses from deer hunters interviewed on Prince of Wales Island, Alaska. A ranking of 1 indicates the most popular habitat; 7, the least popular.

\begin{tabular}{lccc}
\hline Habitat type & All & Hunters using boats & Hunters using vehicles \\
\hline Muskeg & 1 & 1 & 2 \\
Clear-cut forest & 2 & 5 & 1 \\
Alpine & 3 & 4 & 3 \\
Old-growth forest & 4 & 2 & 4 \\
Beach/shoreline & 5 & 3 & 5 \\
Second-growth forest at the stem & 6 & 6 & 6 \\
exclusion stage & 7 & 7 & 7 \\
Recently precommercially thinned forest & 7 & &
\end{tabular}

clear-cut forest, a preferred habitat type for hunting deer (Table 2). Nonetheless, hunters perceived a decline in hunt quality along roads over time because of increased hunting pressure and forest regrowth next to roads. Road closures have caused $47 \%$ of the hunters interviewed to change their hunting strategies. Furthermore, some hunters noted that they seek out and select areas with closed roads to avoid competition with other hunters and because they believe there are more deer in those areas.

Responses were similar between hunters who used boats and hunters who used vehicles for all questions about roads except for how road closures affected harvesting effort $\left(c^{2}=4.593, P=0.032\right)$ and deer populations $\left(c^{2}=5.128, P=0.024\right)$. Fifty percent of the hunters using vehicles reported more harvesting effort because of closures, and only $20 \%$ of boat hunters reported more effort. However, $90 \%$ $(\mathrm{SE}=3 \%)$ of hunters using boats believed that road closures increase deer numbers compared to hunters using vehicles $(61 \%, \mathrm{SE}=5 \%)$. Hunters who changed their hunting strategies because of road closures $(47 \%)$ traveled further from home (MannWhitney $U=620.5, P=0.043$ ) and walked further from their boats or vehicles when hunting (MannWhitney $U=669.5, P=0.042$ ) compared to those who did not change their hunting strategies. Hunters who perceived that deer populations had increased with an increased road network traveled further from home on average compared to those who perceived that the increased road network had decreased deer numbers or had no effect $\left(c^{2}=\right.$ $10.566, P=0.005$ ). Further, on average, hunters who believed that deer populations increased with road closures traveled less distance from home to hunt compared to those who perceived that road closures have not affected deer numbers $\left(c^{2}=7.339, P=\right.$ 0.007).

The beliefs of hunters concerning the effects of roads on harvest opportunities and deer populations influenced their selection of hunting areas. Hunters who preferred clearcuts reported that harvest success increased $\left(c^{2}=10.754, P=0.005\right)$ and harvest effort decreased $\left(c^{2}=7.904, P=0.019\right)$ as roads increased. They also reported that effort increased when roads were closed $\left(c^{2}=8.075, P=\right.$ $0.018)$. Further, hunters who believed that roads increased or did not affect deer populations $\left(c^{2}=\right.$ $16.584, P=0.000)$ and that road closures $\left(c^{2}=6.265\right.$, $P=0.012$ ) had no effect on deer populations tended to prefer hunting in clearcuts. Hunters who reported a decrease in harvest success because of road closures typically had a higher preference for hunting beaches compared to other hunters $\left(c^{2}=\right.$ 
Fig. 3. Changes in area $\left(\mathrm{km}^{2}\right)$ of popular permanent habitat types within $3.2 \mathrm{~m}$, i.e., the median distance hunters travel on foot from boats or vehicles while hunting, and $1.0 \mathrm{~km}$ from a road at peak, current (2006), and future (2015) road densities. Areas $<1 \mathrm{~km}$ from a road are assumed to be readily accessible habitat for hunting.

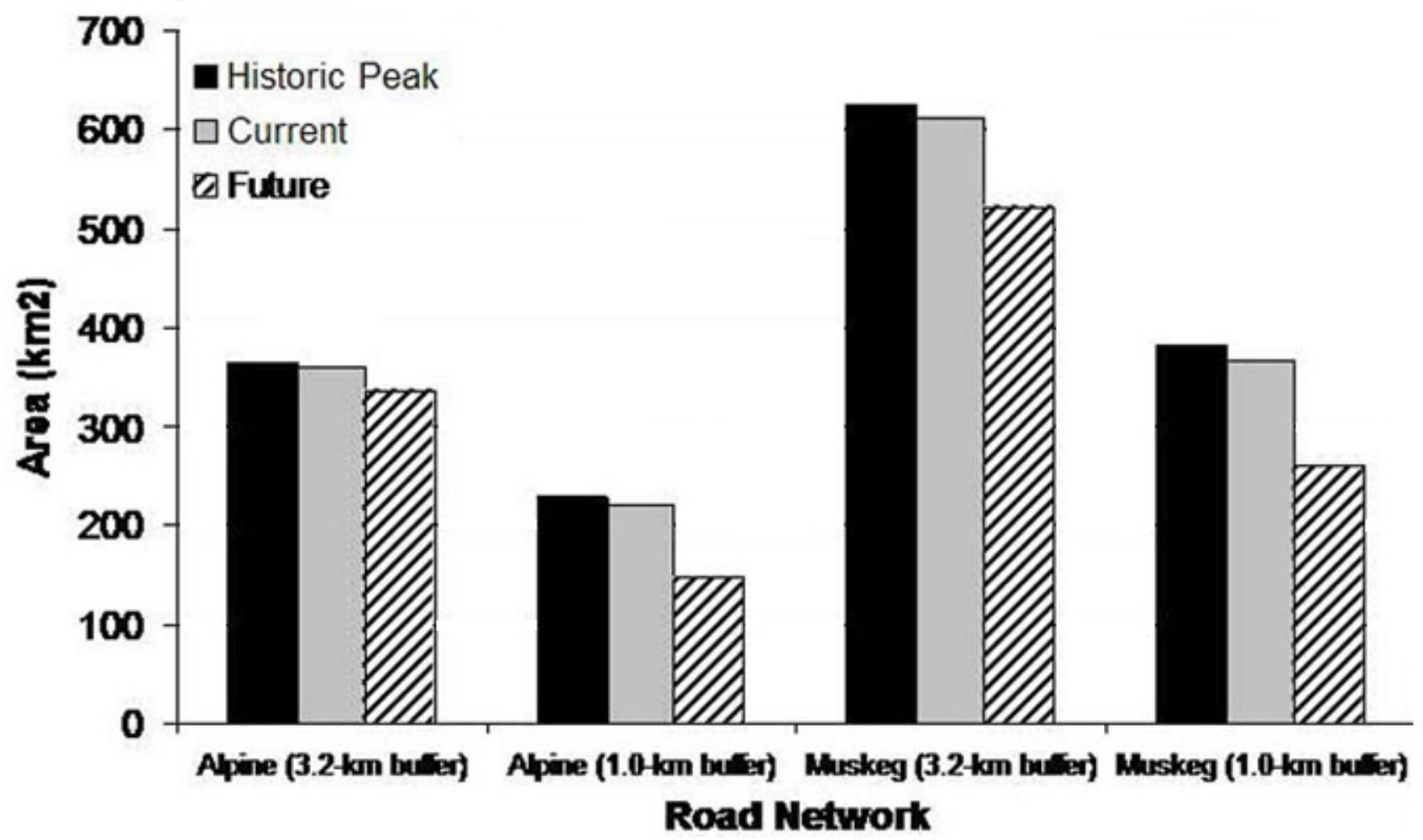

$6.265, P=0.026)$. One suggested explanation for this relationship was that more road closures may lead to more people using boats to hunt, resulting in the perception that hunter competition will increase in beach habitat. Hunters who reported that they had not changed their hunting strategy because of road closures had a higher preference for hunting in muskegs compared to hunters who had changed their strategies $\left(c^{2}=3.928, P=0.048\right)$.

\section{Changes in forest structure}

Hunters indicated that deer harvest opportunities in a clearcut depended on the age of the clearcut or the stage of succession. Hunters reported that hunting was best in young clearcuts (median $=2 \mathrm{yr}$, range $=5$ ), and that hunt quality began to decline after about a decade after cutting (median $=9 \mathrm{yr}$, range
$=18)$. Looking at harvest activity since 1950, the area of clear-cut forest at a desirable stage for hunting (0-8 yr) peaked in the 1970s and has declined rapidly since the mid-1990s (Fig. 4). From 1973 to 2006, the area of clearcuts $<9$ yr of age declined $86 \%$. Eighty-six percent of hunters reported that clearcuts eventually become unhuntable and that this occurred at a median age of $12 \mathrm{yr}$ (range $=42$ ) after clear-cutting. Seven percent $(\mathrm{SE}=9 \%$ ) of hunters believed that a secondgrowth forest could eventually be hunted again with proper management such as thinning. Many hunters $(64 \%, \mathrm{SE}=5 \%)$ said that thinned habitat decreased the quality of the hunt and that they avoided those areas because of a lack of deer, low visibility, and the difficulty in walking through recently thinned habitat. During the thinning process, the canopy is opened, but the thinned trees are left on the ground 
Table 3. Responses by percentage from deer hunters interviewed on Prince of Wales Island, Alaska, to questions addressing the influence of roads and road closures on hunting success, hunting effort, and deer population size.

\begin{tabular}{|c|c|c|c|}
\hline Question & Increased & Decreased & No effect \\
\hline How have road construction and the road network affected hunting success? & $59 \%$ & $10 \%$ & $31 \%$ \\
\hline How have road construction and the road network affected hunting effort? & $9 \%$ & $47 \%$ & $44 \%$ \\
\hline How have road closures affected hunting success? & $33 \%$ & $25 \%$ & $41 \%$ \\
\hline How have road closures affected hunting effort? & $43 \%$ & $9 \%$ & $48 \%$ \\
\hline How have road construction and the road network affected deer populations? & $16 \%$ & $49 \%$ & $35 \%$ \\
\hline How have road closures affected deer populations? & $68 \%$ & $0 \%$ & $32 \%$ \\
\hline
\end{tabular}

wherever they fall, resulting in thick timber debris $1-2 \mathrm{~m}$ in height. The remaining hunters $(36 \%, \mathrm{SE}$ $=5 \%$ ) reported that thinning had increased the quality of hunting in those areas, or that they believed thinning would improve the quality of their hunt in the future. Forty-nine percent $(\mathrm{SE}=5 \%)$ of hunters believed that second-growth forest could never be hunted again regardless of management. In contrast, $44 \%(\mathrm{SE}=5 \%)$ of hunters believed that second-growth forest could be hunted again 25 to $100 \mathrm{yr}$ after a clearcut (median $=40$ ), but that the quality of the hunt in those areas would be inferior to most other habitat types.

As of 2006, the area of clearcuts $\geq 12 \mathrm{yr}$ in age, $i$. e., in which the hunting was poor, was 25 times greater than the area of clear-cut forest aged $0-8 \mathrm{yr}$, which represented good hunting (Fig. 4). Hunter perceptions of changes in harvest opportunities following clearcuts were similar regardless of their mode of access, distance traveled from home to hunting area, distance traveled on foot while hunting, opinions on the effects of roads, and individual preferences for hunting areas.

\section{DISCUSSION}

Hunting systems throughout the world face challenges from logging (Robinson and Bennett 2000). Similar to Prince of Wales Island, commercial logging in tropical forests created vast road networks that penetrated previously inaccessible habitat, leading to increased subsistence opportunities, changes in local economies and patterns of resource consumption, and increased numbers of immigrant workers dependent on local resources (Robinson et al. 1999). Vehicle-based hunting focusing on clear-cut habitat was initially fostered by intensive logging on Prince of Wales (Brinkman et al. 2007). However, the decline in logging has begun to hinder that strategy and challenge the resilience of the hunting system at institutional and individual levels. The changes that have occurred on Prince of Wales created two novel social-ecological trends that function at large spatial, i.e., landscape, and temporal, i.e., decadal, scales. The first change in dynamics was the expanded harvesting opportunities initiated by a boom in commercial logging that rapidly changed the forest structure. The second change in dynamics began as clearcuts transitioned into an undesirable habitat for hunting approximately eight years later. The impact of this ecological change on hunting opportunities was obscured until logging activity declined. With the collapse of commercial logging, the negative effects on hunting success from the successional loss of favorable deer habitat began to overshadow the positive effects of clear-cutting on deer habitat. Currently, the harvest strategies used by one to three generations of hunters are becoming less efficient, and hunting success using current practices is being constrained. 
Fig. 4. Change in areas $\left(\mathrm{km}^{2}\right)$ of managed forest considered "good" and "poor" habitat for deer hunting based on responses from deer hunters interviewed on Prince of Wales Island, Alaska.

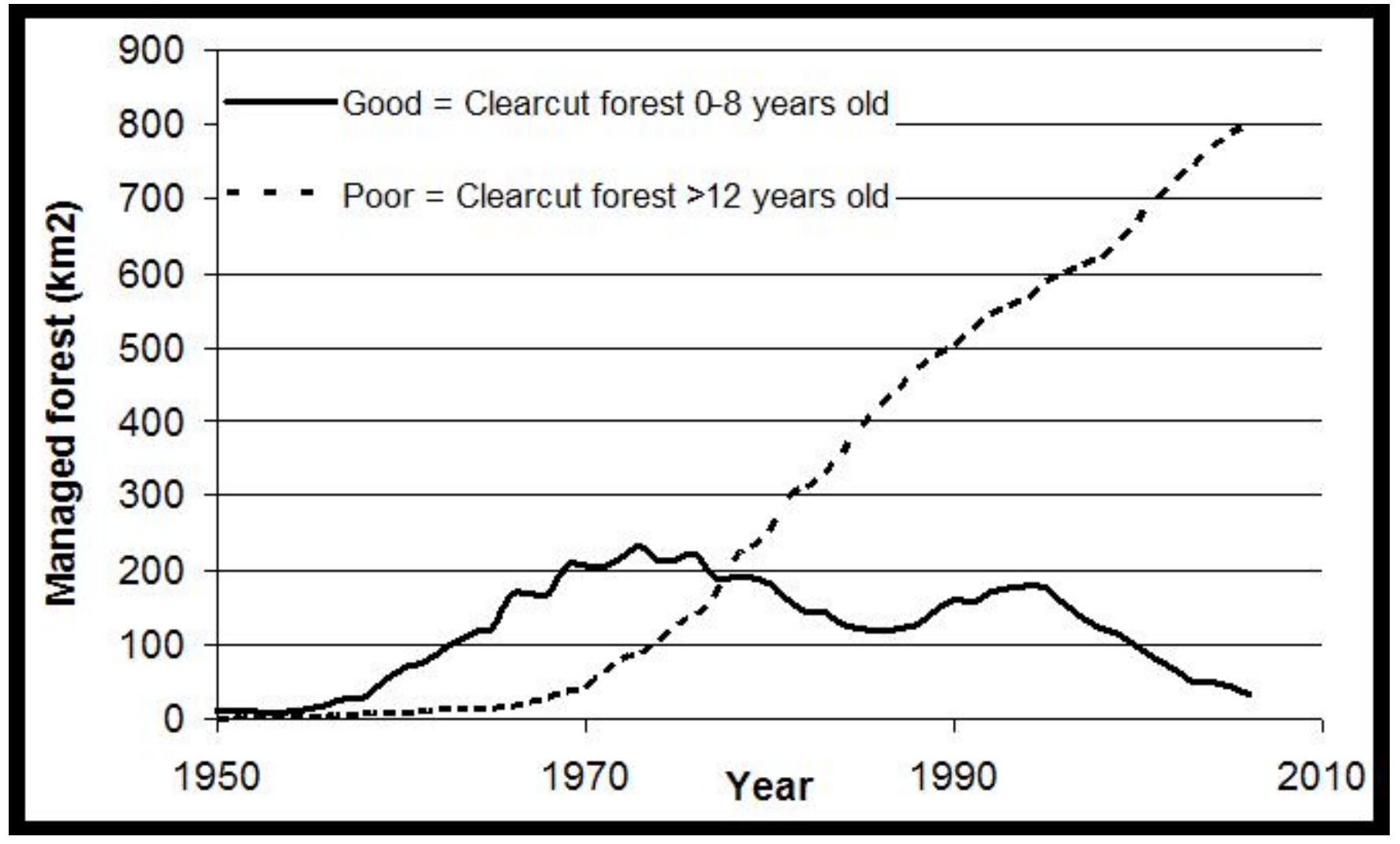

Road closures will further reduce the number of vehicle-accessible areas that are available for deer hunting. Because the main arteries of the road network on Prince of Wales Island will be maintained with the projected closures, a large portion of the preferred habitats currently available for hunting, such as alpine and muskeg, will remain within the median distance that experienced hunters travel on foot. However, because fewer preferred habitats will be directly adjacent to maintained roads, hunters may have to exert more physical effort walking to preferred hunting areas and carrying their harvest back.

The decline in the area of young clear-cut forest may have the greatest influence on deer harvesting opportunities. Because of the decline in the timber industry, young clearcuts will become uncommon within the next decade regardless of road or boat access. Most clearcuts have reached an unsuitable stage for hunting because the patches now consist of either dense stands of even-aged saplings with thick understory vegetation or dense second-growth stands with stem exclusion. Because these stands are located along roads, the ability of hunters to sight deer from roads and harvest them efficiently has decreased (Farmer et al. 2006). The amount of habitat unsuitable for hunting, e.g., second-growth and precommercially thinned forest, has increased rapidly (Fig. 4), and this trend will likely continue.

\section{Adaptation options}

\section{Individual choice}

Responses by individual hunters may be the most feasible form of adaptation to build resilience into the hunting system. This is typical of many northern indigenous people, who are proud of their ability to 
adapt to changing conditions. This hunter adaptation would require no changes in harvest regulations and no manipulation of forest structure and access. Hunters who focus their efforts on permanent and naturally occurring open habitat, e. g., alpine tundra, muskeg, shoreline, are the least vulnerable to logging-associated changes in vegetation and are likely to have more success sustaining their harvest opportunities in the future. On the other hand, those hunters who depend on vehicles for access, concentrate their hunting efforts in young clearcuts, and are unwilling or unable to travel on foot away from maintained roads are particularly vulnerable to forest changes. Vulnerable hunters who are unwilling or unable to adapt may have to reduce their reliance on deer for meat and expand their harvest of marine resources if they wish to sustain their subsistence lifestyle (Brinkman et al. 2007). An important alternative strategy with reduced harvesting of deer is an increased use of the marine resources that have historically provided for subsistence needs (Alaska Department of Fish and Game 2001). Although this option may be available, any reduction or abandonment of deer would result in the loss, or greatly reduced harvest, of this culturally and nutritionally desirable staple, given its role as the only major terrestrial prey item and red meat resource.

The overall numbers of deer hunters and deer harvested have not declined despite recent decreases in the extent of young clearcuts. This may indicate that challenging hunting conditions have not yet reached a threshold that triggers the abandonment of traditions. Alternatively, hunters may already exhibit resilience to changes by responding adaptively. For instance, interview data from this study indicate that many hunters have already responded to forest change in a way that shows a willingness to expend greater effort to carry on their deer hunting traditions. For instance, the $47 \%$ of hunters who reported that they altered their harvest strategies because of road closures also walked further on average when hunting compared to those who have not changed their harvesting strategies. In addition, some hunters reported a preference for closed roads because they believed deer numbers were greater in areas in which roads were closed to vehicle use. Consequently, hunting success may increase as a result of road closures as long as habitats within those areas remain huntable and support deer. The success rates of elk hunters in Idaho were reported to be several times higher in roadless areas compared to roaded and logged areas, purportedly because of a greater density of elk in roadless areas compared to logged areas and areas near roads (Thiessen 1976). Clearly, hunters will need to expend greater effort as roads are closed, but increases in the success in roadless or vehiclerestricted areas may at least partially compensate for reduced convenience and increased effort. In contrast, hunters who continue to hunt mainly along the condensed road system will likely experience greater competition from other road hunters, which may lower their success rates (Brinkman et al. 2007). Because many hunters reported that the number of deer seen along roads while driving was used an indicator of population size on Prince of Wales Island, fewer roads with less visibility from roads also may create a false perception of a declining deer population.

\section{Forest management}

From an institutional perspective, active cutting of second-growth forest and road closure strategies that minimize loss of access to preferred hunting areas may serve as adaptation options that help sustain deer-harvesting opportunities. Manipulation of forest structure and access would require relatively few changes in harvest regulations and hunter strategies. The harvest of older, i.e., 50- to 60-yr-old, second-growth forest could increase the area of young clear-cut habitat and potentially provide the revenue necessary to maintain roads that are important for the harvesting of local resources such as fuelwood, berries, and wildlife. If a market for 60-yr-old timber were identified, forest managers would have an incentive to keep roads open to foster the efficiency of revenue-generating timber sales rather than rebuild roads every 50 to 60 yr. With a market for 60-yr-old timber, an annual average up to $14 \mathrm{~km}^{2}$, which is 5.8 times the level harvested in 2006, of second-growth forest could be made available for potential conversion back to clear-cut habitat between the years 2010 and 2030 . This would create up to $112 \mathrm{~km}^{2}$, or 2.3 times the 2006 level, of desirable 0- to 8-yr-old clear-cut habitat for deer hunting during that time period with little or no cost of additional road construction. According to our spatial analysis of harvested areas, $183 \mathrm{~km}^{2}$ of second-growth forest harvested between 1950 and 1970, i.e., logged forest that would turn 60 between 2010 and 2030, was intersected by roads, excluding roads on private or native-owned land, that were closed or scheduled to be decommissioned. The future road system will 
intersect $207 \mathrm{~km}^{2}$ of old second-growth forest logged in 1950-1970, resulting in 47\% of secondgrowth forest becoming inaccessible by road. Given the recent and projected closure of roads accessing second growth, it appears unlikely that a potential second harvest has received or will receive serious consideration in the near future. Moreover, high fuel and labor costs may discourage the development of a large market for second growth in southeast Alaska. U.S. Forest Service decisions on road maintenance and management strategies are complex and involve more than second-growth harvest and the availability of deer, including the relative value of roads in terms of safety, access needed, and current uses (PBS Engineering and Environmental 2005). Problems associated with important resources such as fish, wildlife, vegetation, and water are typically considered during the benefit/cost assessment. Many closed roads will be placed under "storage" status, which means that they will be closed for now but could be reopened in the future.

Another forest management option to restore deerharvesting opportunities for vehicle-based hunters who prefer clearcuts is additional harvesting of the remaining old-growth forest. This could provide a temporary solution for those who prefer hunting in young clearcuts but would further hinder the longterm sustainability of the hunting system by increasing the overall proportion of poor habitat for deer and deer hunting a decade later. Further, oldgrowth timber from Alaska struggles to compete with timber from other regions, and production has been stagnant or has declined in recent years (Morse 2000, Brackley et al. 2006).

\section{Deer management}

In regions with ineffective enforcement, e.g., some tropical forest regions, in which the harvesting of wild game or "bushmeat" is a source of income, the increase in the availability of game following logging may result in overexploitation and unsustainable hunting (Wilke and Carpenter 1998, Robinson and Bennett 2000, Laurance 2001, Fredericksen and Putz 2003). Limiting access can be a useful management tool to reduce the size of the harvest (Hieb 1976, Cole et al. 1997). In southeast Alaska, however, much of the range of Sitka black-tailed deer is an archipelago composed of remote areas that are relatively inaccessible to hunters, so overexploitation through human harvest is unlikely to occur at a regional scale. Nonetheless, even if deer populations remain regionally stable, hunting pressure and human disturbance can reduce game densities at smaller, e.g., watershed, scales in easily accessible areas such as habitats adjacent to roads (Hieb 1976). Farmer et al. (2006) noted that deer are at higher risk of mortality near roads and avoid open habitat such as muskeg near roads. Perry and Overly (1976) also found that roads reduced the use of adjacent habitat by deer, particularly in open vegetation types. If hunters on Prince of Wales prefer open habitat types near roads, but deer densities are not necessarily the highest in these areas, then their access and ability to see deer may be equal to or more important than the supply or deer densities as a determinant of hunter success and effort. Therefore, a management strategy focused on access and habitat manipulation may produce more harvesting opportunities than a strategy focused on maintaining population levels.

An emphasis on access points at the patch scale may also make it possible to monitor harvest efficiency, either to assess potential impacts on local deer populations or to develop strategies for efficient subsistence harvesting. The differences between boat and vehicle users in terms of their preferences and focus on specific habitat types demonstrate that hunters interact with the landscape at the patch scale in ways that depend on the distance and type of access, i.e., road or shoreline. Implementing harvest restrictions, e.g., by reducing the number of hunting permits issued or imposing stricter eligibility requirements for hunters, to reduce hunting pressure in desirable habitat for deer hunting might help those who remain eligible to sustain their harvest opportunities using currently popular hunting strategies. Also, this would reduce the need to actively manage second-growth forest. However, this policy would only delay the inevitable reduction in opportunities for all hunters owing to ecological changes (Brinkman et al. 2007). Using political tools to further restrict hunter eligibility to temporarily sustain the harvest for increasingly fewer hunters would lead to greater conflict and less compliance amongst hunter groups, especially if the deer population size could sustain a higher harvest without affecting conservation goals.

If areas easily accessed by people serve as population sinks for deer, another approach to maintaining harvesting opportunities is to manage population sources, e.g., productive recruitment habitat, relatively close to access points to counter hunting pressure. In South America, for example, 
Novaro et al. (2000) suggested that the dispersal of wild game from remote and productive refugia to actively hunted sites was important when evaluating the sustainability of subsistence hunting systems.

Biologists have speculated that the area's overall carrying capacity might decline if the logging of old-growth forests caused the loss of critical winter habitat (Schoen et al. 1988), although no data are currently available to test for a relationship between deer numbers and habitat change in southeast Alaska. Additional research focusing on how deer densities change with forest succession and changes in access will be critically important when evaluating and modeling the sustainability of the hunting system. This information will be needed before wildlife researchers, forest managers, and local hunters can confidently move forward together toward a more sustainable hunting system. Because hunters often focus on the patch scale, data on change in deer density by habitat patch may be the most useful when attempting to determine dynamic relationships among hunters, deer, and the land.

The potential methods of adaptation that we observed are similar to the patterns observed in many resource-based social-ecological systems. Hunters readily adapted to increased resource accessibility that reduced their hunting effort, just as society in general responds positively to regulatory and technological changes that increase their access to resources (Ostrom 1990). As deer accessibility declined, the continued harvesting of marine food and the willingness of about half of the hunters to increase their hunting efforts suggested at least two modes of individual adaptation that provided resilience in the face of declining deer accessibility. Both of these adaptations are embedded in traditional use patterns. Policy changes that initiate second-growth cutting or retain more roads adjacent to open habitat are potential institutional avenues of adaptation to sustain the deer harvest. However, to date, subsistence hunting issues have not influenced forestry policies regarding road maintenance and the harvesting of second-growth forests. Perhaps surprisingly, changes in deer management showed little potential to facilitate adaptation, because deer accessibility appeared more strongly influenced by road access and successional changes in forest structure than by variations in population dynamics. Research on deer population trends and the role of inaccessible source populations on deer densities near roads might provide further insights. These observations suggest that adaptations by individual hunters have so far contributed more to the resilience of this hunting system than have adjustments by management agencies, which would likely require more communication among agencies and stakeholders and the development of shared goals among hunters, foresters, and wildlife biologists.

Responses to this article can be read online at: http://www.ecologyandsociety.org/voll4/iss 1/art36/ responses/

\section{Acknowledgments:}

We thank the hunters who participated in this study for kindly sharing their time, knowledge, and hunting experiences. Craig Community Association, Hydaburg Cooperative Association, and Klawock Cooperative Association assisted with interview participation and scheduling. We thank R. Jacobson and J. Stevens for providing GIS spatial data. The Division of Wildlife of the Alaska Department of Fish and Game and the USDA Forest Service provided logistical support. Funding was provided by the Alaska Trappers Association, the Resilience and Adaptation Program (IGERT, NSF 0114423), the Bonanza Creek LTER (funded jointly by NSF grant 0423442 and USDA Forest Service, Pacific Northwest Research Station grant PNWO1JV11261952-231), and the University of Alaska Fairbanks Biology and Wildlife Department and Institute of Arctic Biology.

\section{LITERATURE CITED}

Alaback, P. B. 1982. Dynamics of understory biomass in Sitka spruce-western hemlock forests of southeast Alaska. Ecology 63:1932-1948.

Alaska Department of Fish and Game. 2000. Subsistence in Alaska: a year 2000 update. Alaska Department of Fish and Game, Division of Subsistence, Douglas, Alaska, USA. Available online at: http://www.subsistence.adfg.state.ak.us/ download/subupd00.pdf.

Alaska Department of Fish and Game. 2001. Community profile database. Alaska Department of Fish and Game, Division of Subsistence, Douglas, 
Alaska, USA. Available online at: http://www.state. ak.us/adfg/subsist/subhome.htm.

Berkes, F. 2008. Sacred ecology: traditional ecological knowledge and resource management. Taylor and Francis, Philadelphia, Pennsylvania, USA.

Beyer, H. L. 2007. Hawth's analysis tools for ArcGIS (version 3.27). Available online at: http://w ww.spatialecology.com/htools/index.php.

Brackley, A. M., T. D. Rojas, and R. W. Haynes. 2006. Timber products output and timber harvests in Alaska: projections for 2005-2025. U.S. Forest Service General Technical Report PNW-GTR-677.

Brinkman, T. J., G. P. Kofinas, F. S. Chapin III, and D. K. Person. 2007. Influence of hunter adaptability on resilience of subsistence hunting systems. Journal of Ecological Anthropology 11:58-63.

Cambell, T. A., B. R. Laseter, W. M. Ford, and K. V. Miller. 2004. Movements of female whitetailed deer (Odocoileus virginianus) in relation to timber harvests in the central Appalachians. Forest Ecology and Management 199:371-378.

Cole, E. K., M. D. Pope, and R. G. Anthony. 1997. Effects of road management on movement and survival of Roosevelt elk. Journal of Wildlife Management 61(4):1115-1126.

Doerr, J. G., E. J. Degayner, and G. Ith. 2005. Winter habitat selection by Sitka black-tailed deer. Journal of Wildlife Management 69(1):322-331.

Ellanna, L. J., and G. K. Sherrod. 1987 timber management of fish and wildlife use in selected southeastern Alaska communities: Klawock, Prince of Wales Island, Alaska. Technical Paper Series, No. 126. Alaska Department of Fish and Game, Division of Subsistence, Juneau, Alaska, USA.

Emmons, G. T. 1991 The Tlingit Indians. University of Washington Press, Seattle, Washington, USA.

Farmer, C. J., D. K. Person, and R. T. Bowyer. 2006. Risk factors and mortality of black-tailed deer in a managed forest landscape. Journal of Wildlife Management 70:1403-1415.
Fredericksen, T. S., and F. E. Putz. 2003. Silvicultural intensification for tropical forest conservation. Biodiversity and Conservation 12:1445-1453.

Folke, C. 2004. Traditional knowledge in socialecological systems. Ecology and Society 9(3): 7. [online] URL: http://www.ecologyandsociety.org/vol9/ iss3/art7/.

Hieb, S. R, editor. 1976. Proceedings of the elklogging-roads symposium. University of Idaho, Moscow, Idaho, USA.

Klein, D. R., and S. T. Olson. 1960. Natural mortality patterns of deer in southeast Alaska. Journal of Wildlife Management 24:80-88.

Kofinas, G. 2002. Community contributions to ecological monitoring: knowledge co-production in the U.S.-Canada Arctic borderlands. Pages 54-91 in I. Krupnik and D. Jolly, editors. The Earth is faster now: indigenous observations of Arctic environmental change. ARCUS, Fairbanks, Alaska, USA.

Kruse, J., and R. Frazier. 1988. Community profile series. Volume 2. Klawock-Yakutat. Tongass Resource Use Cooperative Study. Institute of Social and Economic Research, Memorial University of Newfoundland, St. John, Newfoundland, Canada.

Langdon, S. J. 1977. Technology, ecology, and economy: fishing systems in Southeast Alaska. Dissertation. Stanford University, Palo Alto, California, USA.

Laurance, W. F. 2001. Tropical logging and human invasions. Conservation Biology 15:4-5.

Martin, J. L., and C. Baltzinger. 2002. Interaction among deer browsing, hunting, and tree regeneration. Canadian Journal of Forest Research 32:1254-1264.

Mazza, R. 2003. Hunter demand for deer on Prince of Wales Island, Alaska: an analysis of influencing factors. U.S. Forest Service General Technical Report PNW-GTR-581.

Morse, K. S. 2000. Responding to the market demand for Tongass timber. U.S. Forest Service, Region 10, Juneau, Alaska, USA. Available online at: http://www.fs.fed.us/r10/ro/policy-reports/for_mgmt/ index.shtml. 
Novaro, A. J., K. H. Redford, and R. E. Bodmer. 2000. Effect of hunting in source-sink systems in the Neotropics. Conservation Biology 14:713-721.

Osgood, W. H. 1901. Natural history of the Queen Charlotte Islands, British Columbia. North American Fauna No. 21. U.S. Department of Agriculture, Division of Biological Survey, Washington, D.C., USA.

Ostrom, E. 1990. Governing the Commons: the evolution of institutions for collective action. Cambridge University Press, Cambridge, UK.

PBS Engineering and Environmental. 2005. Roads analysis. U.S. Forest Service, Ketchikan, Alaska, USA.

Perry, C., and R. Overly. 1976. Impact of roads on big game distribution in portions of the Blue Mountains of Washington. Pages 62-68 in S. R. Hieb, editor. Proceedings of the elk-logging-roads symposium. University of Idaho, Moscow, Idaho, USA.

Pojar, J. 1994. Plants of the Pacific northwest: Washington, Oregon, British Columbia, andAlaska. Lone Pine Publishing, Redmond, Washington, USA.

Porter, B. 2005. Unit 2 deer management report. Pages 39-57 in C. Brown, editor. Deer management report of survey and inventory activities 1 July 2002-30 June 2004. Alaska Department of Fish and Game, Juneau, Alaska, USA.

Rao, M., and P. J. K. McGowan. 2002. Wild-meat use, food security, livelihoods, and conservation. Conservation Biology 16:580-583.

Robinson, J. G., and E. L. Bennett. 2000. Hunting for sustainability in tropical forests. Columbia University Press, New York, New York, USA.

Robinson, J. G., K. H. Redford, and E. L. Bennett. 1999. Wildlife harvest in logged tropical forests. Science 284:595-596.

Schoen, J. W., M. D. Kirchhoff, and J. H. Hughes. 1988. Wildlife and old-growth forests in southeastern Alaska. Natural Areas Journal 8:138-145.
Southeast Alaska GIS Library. 2007. Spatial data at UAS. Available online at: http://gina.uas.alaska.edu

Southeast Alaska Subsistence Regional Advisory Council.2005. Unit 2 Deer Management. Southeast Alaska Subsistence Regional Advisory Council, Unit 2 Deer Planning Subcommittee, Anchorage, Alaska, USA.

Thiessen, J. L. 1976. Some relations of elk to logging, roading, and hunting in Idaho's game management unit 39. Pages 3-5 in S. R. Hieb, editor. Proceedings of the elk-logging-roads symposium. University of Idaho, Moscow, Idaho, USA.

Turek, M. F., R. F. Schroeder, and R. Wolfe. 1998. Deer hunting patterns, resource populations, and management issues on Prince of Wales Island. Alaska Department of Fish and Game, Division of Subsistence, Juneau, Alaska, USA.

U.S. Department of Agriculture. 2007. Tongass land and resource management plan amendment: draft environmental impact statement. U.S. Forest Service, Ketchikan Alaska, USA.

Wallmo, O. C, and J. W. Schoen. 1980. Responses of deer to secondary forest succession in southeast Alaska. Forest Science 26:448-462.

Watson, A., L. Alessa, and B. Glaspell. 2003. The relationship between traditional ecological knowledge, evolving cultures, and wilderness protection in the circumpolar north. Conservation Ecology 8(1):2. [online] URL: http://www.consecol.org/vol8/iss1/art2/

Wilke, D. S., and J. F. Carpenter. 1999. Bushmeat hunting in the Congo Basin: an assessment of impacts and options for mitigation. Biodiversity and Conservation 8:927-955.

Wolfe, R.J. 2004 Local traditions and subsistence: a synopsis of twenty-five years of research in Alaska. Technical Paper No. 284. Alaska Department of Fish and Game, Division of Subsistence, Juneau, Alaska, USA. 